\title{
Phytochemicals and Nutritional Characteristics of Ethanol Extract of the Leaf and Bark of Njangsa (Ricinodendron Heudelotii) Plant
}

\section{${ }^{* 1}$ UZOEKWE, NGOZY MAUREEN; ${ }^{2}$ HAMILTON- AMACHREE, AKENS}

\author{
"Department of Basic Science, Benson Idahosa University, Benin city, Nigeria \\ ${ }^{2}$ Department of Chemistry, Federal University Otuoke, Bayelsa State, Nigeria \\ Corresponding author: Uzoekwe, N.M. Email: ng_uzoekwe@yahoo.com;
}

\begin{abstract}
The phytochemical, proximate and mineral content of leaf and bark of Njangsa (Ricinodendron Heudelotii) plant were analysed, using standard procedures described by Harbone, 1973, Sofowora, 1993; Trease and Evans, 1989 and Association of Official Analytical Chemist (AOAC) Official method, 1990; 1984 respectively. The preliminary phytochemical screening revealed the presence of tannins, steroids, terpernoids, alkaloids, flavonoids, cardiac glycosides, reducing sugars and saponins found only for the plant bark. The result of proximate analysis showed that the leaf and bark of the extract contain respectively: moisture content $(25.80 \%$ and $10 \%)$, protein $(17.47 \%$ and $3.73 \%)$, crude fat $(1.80 \%$ and $2.00 \%)$ ash $(11.00 \%$ and $10.95 \%)$, crude fibre $(41.00 \%$ and $20.50 \%)$ carbohydrate $(2.93 \%$ and $52.82 \%)$. The mineral analysis of the plant leaf and bark respectively yielded calcium - $2640.00 \mathrm{mg} / \mathrm{kg}$ and $1772 \mathrm{mg} / \mathrm{kg}$, magnesium $-2383 \mathrm{mg} / \mathrm{kg}$ and $1605 \mathrm{mg} / \mathrm{kg}$, iron $-25.00 \mathrm{mg} / \mathrm{kg}$ and $6.6 \mathrm{mg} / \mathrm{kg}$, zinc $-29.30 \mathrm{mg} / \mathrm{kg}$ and $4.4 \mathrm{mg} / \mathrm{kg}$, copper - $14.60 \mathrm{mg} / \mathrm{kg}$ and $6 \mathrm{mg} / \mathrm{kg}$ and phosphorus $-1012 \mathrm{mg} / \mathrm{kg}$ and $305 \mathrm{mg} / \mathrm{kg}$. Manganese was absent in the bark but yielded $1.1 \mathrm{mg} / \mathrm{kg}$ in the leaf. Sodium and potassium were found to be absent in the leaf and bark. The presence of some phytochemicals (flavonoids, cardiac glycosides, reducing sugar, tannins and terpernoids) and some essential minerals suggest that it is a potential source of medicine and food.

(C) JASEM
\end{abstract}

http://dx.doi.org/10.4314/jasem.v20i3.5

Keywords: Phytochemical, Nutritional Characteristics, Proximate, Mineral, Medicinal, Analysis.

Phytochemicals are naturally occurring and are believed to be effective in combating or preventing diseases due to their antioxidant effect (Haliwell and Gutteridge, 1992; Ejele et al., 2012). A single plant may be used for the treatment of various disease conditions depending on the community. Several ailments including fever, asthma, constipation, esophageal cancer and hypertension have been treated with traditional medicinal plants (Saganuwan, 2010). The plants are applied in different forms such as poultices, concoctions of different plant mixtures, infusions such as teas or tinctures or as component mixtures in porridges and soups administered in different ways including oral, nasal (smoking, snuffing or steaming), topical (lotions, oils or creams), bathing or rectal (enemas). Different plant parts and components (roots, leaves, stem barks, flowers or their combinations, essential oils) have been employed in the treatment of infectious pathologies in the respiratory system, urinary tract, gastrointestinal and biliary systems, as well as on the skin (Rojas et al., 2001; Rois and Recio, 2005;Adekunle and Adekunle, 2009). Medicinal plants are increasingly gaining acceptance even among the literates in urban settlements, probably due to the increasing inefficacy of many modern drugs used for the control of many infections such as typhoid fever, gonorrhea and tuberculosis as well as increase in resistance by several bacteria to various antibiotics and the increasing cost of prescription drugs, for the maintenance of personal health (Levy, 1998; Van den Bogaard et al., 2000; Smolinski et al., 2003). Unfortunately, rapid explosion in human population has made it almost impossible for modern health facilities to meet health demands all over the world, thus putting more demands on the use of natural herbal health remedies. Current problems associated with the use of antibiotics, increased prevalence of multiple-drug resistant (MDR) strains of a number of pathogenic bacteria such as methicillin resistant staphylococcus aureus, helicobacter pylori, and MDR Klebsiela pneumonia has revived the interest in plants with antimicrobial properties (Voravuthikunchai and Kitpipit, 2003). In addition, the increase in cases of opportunistic infections and the advent of Acquired Immune Deficiency Syndrome (AIDS) patients and individuals on immunosuppressive chemotherapy, toxicity of many antifungal and antiviral drugs has imposed pressure on the scientific community and pharmaceutical 
companies to search for alternative and novel drug sources. Thus objective of this study is to investigate phytochemical constituents and nutritional characteristics of ethanolic extracts of Ricinodendron Heudelotii, so as to ascertain suitability of its use as herbal medicine and food.

\section{MATERIALS AND METHODS}

Sample collection and identification: The bark and leaves of Njangsa (Ricinodendron Heudelotii) were collected from an open area in Benson Idahosa University, Edo State, Nigeria. The plant was identified and authenticated at the department of Pharmacognosy, Faculty of Pharmacy, University of Benin. The plant materials were rinsed in water, and then air dried for about two weeks. The dried leaves and bark was ground using electric blending machine in the Pharmacognosy Department of University of Benin, and the powdery sample was packed into containers prior to extraction and analysis.

Extraction: $150 \mathrm{~g}$ of the crushed bark and leaves were measured and placed in containers. Absolute ethanol was used to soak the samples for 72hours and supernatant was filtered using a muslin cloth and the solvent evaporated using a rotary evaporator. The dried extract was weighed and kept in the refrigerator at temperature of $-4^{\circ} \mathrm{C}$ for a period of 48hours.

Qualitative Analysis of Phytochemicals: Phytochemicals are bioactive constituents of medicinal plants which are not nutrients but very useful to the plants. Some bioactive constituents of ethanolic extract were analysed qualitatively for flavonoids, tannins, Cardiac glycosides, Saponin, Steroids, terpenoids, anthraquinones, alkaloids and reducing sugars. Phytochemical screening was carried out on the extracted sample using standard procedure to identify the secondary metabolites (alkaloids, tannins, saponins, glycocides etc) using standard experimental procedure (Harbone, 1973; Sofowora,1993 and Trease and Evans, 1989)

Determination of Flavoniods Content: Two methods were used to determine the presence of flavonoids in the plant sample (Sofowara, 1993; Harbrone, 1973). $5 \mathrm{ml}$ of dilute ammonia solution were added to a portion of the aqueous filtrate of each plant extract followed by addition of concentrated $\mathrm{H}_{2} \mathrm{SO}_{4}$. A yellow coloration observed in each extract indicated the presence of flavonoids. The yellow coloration disappeared on standing. Two drops of $1 \%$ aluminum solution were added to portion of each filtrate. A yellow coloration was observed indicating the presence of flavonoids. A portion of the powdered plant sample was in each case heated with $10 \mathrm{ml}$ of ethyl acetate over a steam bath for $3 \mathrm{~min}$. The mixture was filtered and $4 \mathrm{ml}$ of the filtrate was shaken with $1 \mathrm{ml}$ of dilute ammonia solution. A yellow coloration was observed indicating a positive test for flavonoids.

Determination of Tannins Content: $0.5 \mathrm{~g}$ of the dried powered sample was boiled in $20 \mathrm{ml}$ of water in a test tube and filtered. A few drops of $0.1 \%$ ferric chloride was added and observed for brownish green to a blueblack coloration observed.

Determination of Cardiac glycosides Content (KellerKillani test): $5 \mathrm{ml}$ of each extracts was treated with glacial acetic acid containing one drop of ferric chloride solution. This was underplayed with $1 \mathrm{ml}$ of concentrated sulphuric acid. A brown ring of the interface indicates a deoxysugar characteristic of cardenolides. A violet ring may appear below the brown ring, while in the acetic acid layer, a greenish ring is formed just gradually throughout the layer.

Determination of Saponins Content: About $2 \mathrm{~g}$ of powered sample was boiled in $20 \mathrm{ml}$ of distilled water in a water bath and filtered. $10 \mathrm{ml}$ of the filtrate was mixed with $5 \mathrm{ml}$ of distilled water and shaken vigorously for a stable consistent froth. The frothing was mixed with 3 drops of olive oil and shaken vigorously; emulsion was formed indicating the presence of saponins.

Determination of Steroids Content: $2 \mathrm{ml}$ of acetic anhydride was added to $0.5 \mathrm{~g}$ of ethanolic extract of each sample with $2 \mathrm{ml} \mathrm{H}_{2} \mathrm{SO}_{4}$. The color changed from violet to blue or green in some samples indicating the presence of steroids.

Determination of Terpenoids Content (Salkowski test): $5 \mathrm{ml}$ of each extract was mixed with $2 \mathrm{ml}$ of chloroform and concentrated $\mathrm{H}_{2} \mathrm{SO}_{4} \quad(3 \mathrm{ml})$ was carefully added to form a layer. A reddish brown coloration of the interface was formed which is a positive test for the presence of terpenoids.

Determination of Alkaloid Content: $5 \mathrm{~g}$ of the sample was weighed into a $250 \mathrm{ml}$ beaker and $200 \mathrm{ml}$ of $10 \%$ acetic acid in ethanol was added and covered and allowed to stand for $4 \mathrm{~h}$. This was filtered and the extract was concentrated on a water bath to onequarter of the original volume. Concentrated ammonium hydroxide was added dropwise to the extract until the precipitation was complete. The whole solution was allowed to settle and the precipitate was collected and washed with dilute ammonium hydroxide and then filtered. The residue is the alkaloid which was dried and weighed. 
Determination of Reducing Sugar Content: $1 \mathrm{ml}$ of extract (filtrate) was added to boiling fehling's solution A and B in test tube. Color change from blue to green indicated that reducing sugar was present.

Proximate Analysis: The proximate composition (moisture, fat, protein, ash, crude fibre and carbohydrate) of powdery samples of Ricinodendron Heudelotii were determined according to standard procedures outlined by the Association of Official analytical Chemist (AOAC, 1984; 1990).

Determination of Moisture Content: $5 \mathrm{~g}$ of the fresh samples was weighed in a crucible. The crucible was weighed and placed in an oven at $105^{\circ} \mathrm{C}$ for $3 \mathrm{~h}$, until a constant weight for the samples were gotten.

Moisture percentage was then calculated as follows:

moisture percentage $=\frac{\text { intial weight }- \text { final weight }}{\text { weight of sample used }} \times$ 100

Determination of Crude Fat Content: The empty round bottom flask was weighed (initial weight).10g of the sample was placed inside a soxhlet extractor and n-Hexane used as extracting solvent. After the extraction process was completed, the round bottom flask was dried in an oven, and then the final weight was measured using a digital weighing balance. The percentage crude fat was calculated as shown below

crude fat percentage $=$ $\frac{\text { intial weight-final weight }}{\text { weight of sample }} \times 100$

Determination of Ash Content: The crucible was weighed and $5 \mathrm{~g}$ of sample was placed in it, and then later placed in a muffle furnace at $600^{\circ} \mathrm{C}$ for $6 \mathrm{~h}$. The ash obtained was allowed to cool and then it was weighed. Ash content was then calculated as follows:
Percentage Ash $=\frac{\text { intial weight }- \text { final weight }}{\text { weight of sample }} \times 100$

Determination of Crude Protein Content: The crude protein content of the samples was determined using the Microkjeldahl method of AOAC (1984), which involved protein digestion and distillation. The percentage crude protein was calculated from the $\%$ nitrogen as follows:

$\%$ crude protien $=\% N \times F$

Where; $\mathrm{F}$ (conversion factor) is equivalent to 6.25 .

Determination of Crude Fibre Content: The crude fibre was determined using the method of (AOAC, 1990) (method 14: 020). The percentage crude fibre was calculated as per the formula:

Percentage crude fibre $=\frac{\text { weight after drying }}{\text { weight of sample }} \times$ 100

Determination of Mineral Elements Content (AOAC, 1990): Mineral elements estimation indicates the amount of inorganic elements present in the sample. The determination was carried out using standard procedures. During the determination, the sample was first ashed and dissolved in a solvent, and the resultant solution aspirated into air-acetylene flame. The mineral elements determined were; iron $(\mathrm{Fe})$, zinc $(\mathrm{Zn})$, manganese $(\mathrm{Mn})$, calcium $(\mathrm{Ca})$, magnesium $(\mathrm{Mg})$, sodium $(\mathrm{Na})$, potassium $(\mathrm{K})$, phosphorous $(\mathrm{P})$ and copper $(\mathrm{Cu})$ and this was done by spectrophotometric methods, using flame emission spectrophotometer for sodium $(\mathrm{Na})$ and potassium $(\mathrm{K})$ and atomic absorption for the others.

\section{RESULTS AND DISCUSSION}

The phytochemical content of the leaf and bark of Ricinodendron Heudelotii are shown below

Table 1 Phytochemical Constituent of Ethanolic Extract of Leaf and Bark of R. Heudelotii.

\begin{tabular}{lll}
\hline Test & $\begin{array}{l}\text { Ricinodendron } \\
\text { leaf (ethanol) }\end{array}$ & $\begin{array}{l}\text { Ricinodendron } \\
\text { Bark (ethanol) }\end{array}$ \\
\hline Flavonoids & + & + \\
Tannins & + & ++ \\
Cardiac glycosides & +++ & + \\
Saponins & - & + \\
Steroids & + & ++ \\
Terpenoids & ++ & ++ \\
Anthraquinones & - & - \\
Alkaloids & - & - \\
Hager's & & \\
Wagner's & - & ++ \\
Fehlings A and B & ++ & +++ \\
\hline
\end{tabular}

KEY: Highly present $=+++$, moderately present $=++, \quad$ lightly present $=+$ 
Table1 shows that flavonoids, tannins, cardiac glycosides, terpenoids and reducing sugars were present in ethanol extracts of the leaves of Ricinodendron Heudelotii. Alkaloids (Wagner's) were absent, while saponins and terpenoids were detected. Flavonoids, tannins, cardiac glycosides, terpenoids and reducing sugars were present in ethanol extracts of the leaves of Ricinodendron Heudelotii. Alkaloids (Wagner's) were absent in the ethanol extract of the leaves, while saponins and terpenoids were detected. Anthraquinones and alkaloids (Hager's) were absent in the leaves and bark.

Steroids were detected in the ethanol extract but anthraquinones and alkaloids (Hager's) were found to be absent.

Anthraquinones were found to be absent in ethanol extracts of all the samples. Anthraquinones are known to be insoluble in water and cold organic solvents but soluble in hot organic solvents, it is almost completely insoluble in ethanol near room temperature but $2.25 \mathrm{~g}$ will dissolve in $100 \mathrm{~g}$ of boiling ethanol (Macleod and Allen, 1934).
Herbal preparations of the leaves of Ricinodendron Heudelotii which are traditionally used for various medicinal purposes (as a disinfectant, in treating tonsillitis, ophthalmic, stomach and back pain and as a poison for arrows) was found to contain flavonoids, tannins, cardiac glycosides, saponins, steroids, terpenoids, and alkaloids in this study. Plants generally contain chemical compounds called secondary metabolites, which are biologically active (Soetan and Oyewole, 2009). Secondary metabolites may be applied in nutrition and pharmacologically active agent (Soetan and Oyewole, 2009). Plants are also known to have high amounts of essential nutrients, vitamins, minerals, fatty acids and fibre (Gafar and Itodo, 2011; Edeoga et. al; 2005). Therefore, Ricinodendron Heudelotii leaf is a potential source of drugs. Anibogu (1999) reported that Ricinodendron Heudelotii has no known toxicity. Also the bark of Ricinodendron Heudelotii are traditionally used to treat pain, rheumatism, diarrhea, stomach problems, edema in children, infertility rashes, mouth sores, chest problems and as a galacticusogogue. These medicinal properties may be due to the presence of flavonoids, tannins, cardiac glycosides, saponins, steroids, terpenoids and alkaloids

Table 2: Results Proximate Analysis

\begin{tabular}{lllllll}
\hline Samples & Moisture & $\begin{array}{l}\text { Crude } \\
\text { Protein }\end{array}$ & $\begin{array}{l}\text { Crude } \\
\text { Fat }\end{array}$ & Ash & \multicolumn{3}{c}{$\begin{array}{l}\text { Crude } \\
\text { Fibre }\end{array}$} & Carbohydrate \\
& & 5.00 & 3.00 & 4.00 & 78.22 & 5.78 \\
Ricinodendron leaf & 4.00 & 9.85 & 4.40 & 2.60 & 64.00 & 7.26 \\
Ricinodendron bark & 11.89 & & & \\
\hline
\end{tabular}

Table 2. shows that leaves of Ricinodendron Heudelotii has $4.00 \%$ moisture, $5.00 \%$ proteins, $3.00 \%$ crude fat, $4.00 \%$ ash, $78.22 \%$ crude fiber and $5.78 \%$ carbohydrates. These value for crude fiber is comparable to the value obtained by Adebisi and Oyeleke (2009) (moisture-5.77\%, fat-12.21\%, carbohydrate- $30.93 \%$, and crude fiber-37.3\%), while the values for crude fat and carbohydrates are close to the results obtained by Isah, et al. (2013) (moisture$74.60 \%$, protein- $4.96 \%$, crude fat- $0.31 \%$, ash-3.75\%, crude fiber- $7.51 \%$ and carbohydrate-8.87\%). The results indicate that the leaves of Ricinodendron Heudelotii is a good source of fiber, minerals (ash) and proteins, but not a very good source of energy due to low carbohydrate and fat content.

Proximate analysis of the bark of Ricinodendron Heudelotii yielded $11.89 \%$ - moisture, $9.85 \%$-protein, $4.40 \%$-crude fat, $2.60 \%$-ash, $64.00 \%$-crude fiber, and $7.26 \%$-carbohydrate. These values obtained show that the bark of Ricinodendron Heudelotii is a good source of minerals (ash), crude fiber and carbohydrate, but a poor source of protein and crude fat. Results gotten from the leaves and bark extracts showed that, the leaves of Ricinodendron Heudelotii are a better source of proteins than the bark; whereas the bark is a better source of carbohydrates than the leaves.R.Heudelotii is a source of many nutrients and biologically active compounds that include omega -3- fatty acids, essential amino acids, minerals and antioxidant vitamins ( Besong et al; 2011).The leaves are used as important source of high quality folder for sheep and goat in dry season, the values of crude protein determined in this study $(5.0 \%$ for the leave and $9.9 \%$ for the bark) is relatively lower than $16.0 \%$ obtained for green foliage of $R$. heudelotii (Anigbogu, 1996). Manga et. al (2000) reported a total fat content of $R$. heudeloltii Vernels from various locations in Cameroon ranging from 50.0 to $65.2 \%$; being by far higher than $1.8 \%$ and $2.0 \%$ determined in this study for the leaves and the bark of the $R$. heudeloltii respectively. However, it is generally understood that fat content of seed is higher than that of leaf of a particular plant. 
The results reveal that $R$. heudSelotii is rich in fibre; yielding crude fibre content of $78.22 \%$ for the leaf and $64.0 \%$ for the bark.

However, the study reveals that $\mathrm{R}$. heudololtis leaf and bark could be a good source of crude fibre because the value determined $(41.00 \%$ for the leave and $20.50 \%$ for the bark) is by far more than values determined by other authors for plants, even vegetables. The crude fibre for twelve (12) common vegetables consumed in Edo State Nigeria, ranged between $0.6-25.5 \mathrm{~g} / \mathrm{dry}$ weight (Mensah et al; 2008). Shankutala and Shadaksharaswamy(1987) found the fibre content of common table fruits (banana, guava, mango, orange, pawpaw and pineapple) to range between $0.2-5.2 \mathrm{~g} / 100 \mathrm{~g}$ while the value for the wild plants (A. digitata, liafzelli and M. africana) ranged between 27.33-29.48g/100g (Uzoekwe and Agatemor, 2010). The high fibre content of the analyzed plant leave and bark suggest that the sample contains high amount of polysaccharides such as cellulose and hemicellulose. Thus the leaves and bark of the plant could be useful in prevention of cancer of the colon (WCRF,1997; Block et al; 1992).

Table 3: Result of Mineral Composition (mg/100g)

\begin{tabular}{lll}
\hline Parameters & $\begin{array}{l}\text { Ricinodendron } \\
\text { Leaves }\end{array}$ & $\begin{array}{l}\text { Ricinodendron } \\
\text { Bark }\end{array}$ \\
\hline Calcium & 5932 & 4409 \\
Magnesium & 1994 & 2431.20 \\
Sodium & 0.00 & 0.00 \\
Potassium & 0.00 & 0.00 \\
Iron & 32.30 & 15.60 \\
Zinc & 18.60 & 11.50 \\
Copper & 22.70 & 19 \\
Manganese & 41.30 & 27.70 \\
Phosphorous & 688 & 249 \\
\hline
\end{tabular}

Table 3 depicts that Ricinodendron Heudelotii leaves were found to have relatively higher quantities of calcium, magnesium and phosphorus. Iron, zinc, copper and manganese were present but not in very high quantities. Sodium and potassium however, were absent. Calcium, magnesium and manganese which are present in high concentrations are essential minerals for life; they are important in the formation of bones and teeth as a cofactor for enzymes and a component of ATP, DNA, RNA and cell membranes respectively. The minerals present in low concentrations (iron, zinc, copper and manganese) perform various important functions in humans like the formation of hemoglobin, growth and sexual maturation, facilitating iron intake, as cofactor for enzymes and so many other functions (Mensah et al, 2008).The bark of the plant was found to contain all the minerals analyzed with calcium and magnesium present in the highest concentrations.
Conclusion: The high content of crude fibre, protein, calcium, iron, potassium in Ricinodendron Heudelotii makes it rich in nutrients and it can serve as potential nutritious food supplement to improve the health status of its consumers. Also, the presence of phytochemicals in the plants is evidence that it has high medicinal properties.

Acknowledgement: The authors wish to posthumously appreciate efforts of Late Mr. Sunny Akamaguna of Pharmacognosy Department, Faculty of Pharmacy, University of Benin for identifying and authenticating the plant used for this study, May his gentle soul rest in peace.

\section{REFERENCES}

Adebisi, GA; Oyeleke, GA (2009). Studies on Ficus capensis (Fruit and Leaf) Proximate and Mineral Compositions. International Journal of Chemical Sciences. 7 (3): 1765-1761.

Adekunle, AS; Adekunle, OC (2009). Preliminary Assessment of Antimicrobial Properties of Aqueous Extract of Plants against Infectious Diseases. Biology and Medicine. 1(3): 20-24.

Anigbogu, NM (1996). Nature's gifts improving trees and shrubs around the world: $R$. heudelolti in Nigeria. Agroforestry Today 8(2):18.

AOAC (1984): Official Methods of Analysis of the Association of Official Analytical Chemists. $14^{\text {th }}$ edn; Washington. D.C Association of Official Analytical Chemists.

AOAC (1984): Official Methods of Analysis of the Association of Official Analytical Chemists. $15^{\text {th }}$ edn; S.W. Williams (Ed) Washington. D.C 5-9.

AOAC (1990): Official Methods of Analysis of the Association of Official Analytical Chemists. Washington. D.C. 1-50.

Besong, SA; Ezekwe, MO; Ezekwe ,E (2011). Evaluating the Effects of Freeze-Dried Supplement at Purslane (Portulaca Oleracea) on Blood Lipids in Hypercholesterolemic Adults. Int. J. Nutr. Metab. 3: 43-49.

Block, C; Patterson, B; Subur, A (1992). Fruits, Vegetables and Cancer prevention: A Review of the Epidemiological Evidence. Nutri. Cancer, 18(10): $1-29$ 
Edeoga, HO; Okwu, DE; Mbaebie, BO (2005). Phytochemical constituents of some Nigerian medicinal plants. African Journal of Biotechnology. 4(7): 685-688.

Ejele, AE; Dura, IA; Ogukwe, CE; Iwu, IC (2012). Phytochemicals and Antimicrobial Potentials of Basic Metabolites of piper umbellatum, piper guineense, ocimum gratissimium and new bouldia Laevis extracts. Emer.Trends Eng. Appl. Sci.3 (2):

Gafar, MA; Itodo, AU (2011). Proximate and Mineral Composition of Hairy Indigo leaves. Electronic Journal of Environmental, Agricultural and Food Chemistry. 10(3): 2007-2018

Harborne, JB (1973). Phytochemical Methods $3^{\text {rd }}$ ed. Chapman and Hall Ltd. 135 - 203

Haliwell, B; Gutteridge, JMC (1992). Free Radicals, Antioxidants and Human Diseases: Where are we now? J. Lab.Clinic Med.119: 598

Isah, OA; Omorogiuwa, LE; Okunade, SA (2013). Chemical Evaluation some Plants Eaten by Local Breed of Goat in Edo State, Nigeria. The Pacific Journal Science and Tecnology. 14(1): 406-411.

Levy, SB (1998). The Challenge of Antibiotic Resistance. Scientific American. 278:32-39.

Macleod, L C; Allen, CFH (1934). "Benzanthrone". Organic Synthesis. 14(4): 62-60.

Manga ,TT; Foundoun, JM; Kengue, J; Thiengang, C (2000). Chemical composition of R.heudelotii an Indigenous Fruit Tree in Southern Cameroon. Afr. Crop Sci. J. 8:195-201

Mensah , JK; Okoli, RI; Ohaju-Obodo, JO; Eifediyi , K (2008). Phytochemical, Nutritional and Medical Properties of some leafy vegetables consumed by the Edo people Nigene : Africana Journal of Biotechnology, 7(14): 2304-230

Rìos, JL; Recio, MC (2005). Medicinal plants and antimicrobial activity. Journal of

Ethnorpharmacology.00: 80-84

Rojas, V; Gil, JV; Pinaga, F; Manzanzres, P (2001). Studies on Acetic Ester Production by Nonsaccharomices Wine Yeast. Int. J. **Food Microbiology. 170(3):283-289.
Saganuwan, A.S., (2010). Some medicinal plants of Arabian Peninsula. J. med. Plants Reg. 4(9): 766 $-788$

Shakuntala, MN; ShadakSharaswamy, M (1987). Food facts and Principles. New Delhi, Wiley Eastern Limited.

Smolinski, MS; Hamburg, MA; Lederberg, J; (Eds) (2003). Microbial threats to health: Emergence, detection, and response. Washington, DC: Institute of Medicine, National Academies Press. pp 203-210.

Soetan, KO; Oyewole, OE (2009). The need for Adequate Proceeding to Reduce Anti-nutritional Factors in Plants used as Human food and Animal feed. African Journal of food science. 3(9): 223-232.

Sofowora, LA (1993).Medicinal plants and traditional medicine in Africa. Spectrum Books Ltd Ibadan pp 55-71.

Trease, GE; Evans, WC (1989). Pharmacognosy. $11^{\text {th }}$ edn. Braillier Tiridel Can. Macmillian publishers.

Uzoekwe, SA; Agatemor, CA (2010). Nutrient Potentials of some wild -Gathered Topical Fruits: Lannea Afzelli, Mammae Africana and Adansonia Digitata. International Journal of Chemistry. 20(4): 275-279

Van den Bogaard, AE; Stobberingh, EE (2000). Epidemiology of resistance to antibiotics: Links between animals and humans. International Journal of Antimicrobial Agents.14:327-335.

Voravuthikunchai, SP; Kitpipit, L (2003). Activities of Crude Extracts of Thai medicinal plants on methicillin- resistant Staphylococcus aureus. Journal of Clinical Microbiology and Infection.9:236.

World Cancer Research Fund (WCRF) (1997). Food, Nutritional and prevention of Cancer. A global Perspective. Washington D.C; Am. Inst. Cancer Res. 